Jurnal Lakon, 8 (2) 2019

(87-96)

\title{
RELIGIUSITAS WARIA DI SURABAYA
}

The Religiosity of male to female transvestites in Surabaya

\section{FATMAWATI}

Program Studi Magister Kajian Sastra dan Budaya

Fakultas Ilmu Budaya Universitas Airlangga

Jl. Dharmawangsa Dalam Selatan, Surabaya 60286

e-mail: fatmawati-2016@fib.unair.ac.id

\begin{abstract}
Abstrak: Tulisan ini bertujuan mengkaji religiusitas waria di Surabaya dengan menganalisis latar belakang kehidupan dan agama, representasi religiusitas, dan hak kebebasan beragama yang mereka miliki. Penelitian ini bersifat kualitatif dengan teknik pengumpulan data berupa wawancara terstruktur dengan dua responden yang dipilih dengan sengaja (purposive) berdasarkan kriteria tertentu. Data primer berupa transkripsi rekaman wawancara yang didukung oleh data sekunder berupa kajian pustaka. Hasil temuan menunjukkan bahwa para waria di Surabaya memiliki latar belakang kehidupan dan agama yang berbeda. Religiusitas mereka direpresentasikan dengan afiliasi pada agama tertentu, keaktifan di organisasi keagamaan, perilaku altruisme, praktik religiusitas, dan manfaat religius yang mereka peroleh. Hak kebebasan menganut suatu agama termasuk mempertahankan dan mengganti agama telah mereka peroleh namun hak kebebasan menjalankan ibadah keagamaan masih harus diperjuangkan.
\end{abstract}

Kata-kata Kunci: Religiusitas Waria; Waria di Surabaya; Hak Kebebasan Beragama

Abstract: This article aims to examine the religiosity of male to female transvestites in Surabaya by analyzing their background of life and their religion, the representation of their religiosity, and their right to religious freedom. This study uses a qualitative approach. Data are collected by conducting structured interviews with two respondents. They are selected purposively based on certain criteria. The primary data are transcripts of interviews supported by secondary data in the form of a literature review. The findings indicate that male to female transvestites in Surabaya have a different background of life and religion. Their religiosity is represented by their affiliation with certain religions, their participation in religious organizations, altruistic behaviors, religious practices, and benefits they obtain from their religion. They have the right to adhere to any religion including to maintain or to change their religion but still, they have to fight for their right to freedom of religious worship.

Keywords: Male to Female Transvestite's Religiosity; Male to Female Transvestites in Surabaya; Right to Religious Freedom

\section{PENDAHULUAN}

Waria dan agama merupakan dua
entitas yang seringkali dianggap
berlawanan. Waria terlahir sebagai laki-laki
namun dalam perjalanan hidupnya "mereka

melihat diri mereka sendiri sebagai laki-laki dengan jiwa perempuan" (Boellstorff, 2005). Waria berpenampilan layaknya perempuan dengan cara berdandan, memakai busana feminin dan melembutkan suara (Faidah \& Abdullah, 2013). Di antara waria, ada yang

Jurnal Lakon: Kajian Sastra dan Budaya 
mengubah bentuk tubuhnya dengan suntik silikon, meminum pil KB, menjalani operasi plastik, dan mengganti jenis kelamin (Boellstorff, 2005; Praptoraharjo, Navendorff, \& Irwanto, 2015). Masyarakat menganggap transformasi ini melanggar ajaran agama karena telah menyalahi kodrat dan mengubah ciptaan Tuhan (Arfanda \& Anwar, 2015; Latiefah, 2013). Waria dikenal memiliki perilaku seks bebas dan menyimpang, yaitu perzinahan dan sodomi yang termasuk dalam kategori dosa besar dalam setiap ajaran agama. Oleh karena itu, waria umumnya digolongkan pada kelompok umat manusia yang jauh dari nilai-nilai agama. Rahmantyo (2013) mengumpamakan anggapan masyarakat terhadap sifat agama dan waria ini seperti minyak dan air. Waria dan agama saling bertentangan dan tidak bisa menyatu.

Anggapan masyarakat ini tidak sepenuhnya benar. Di beberapa tempat di Indonesia, ada organisasi keagamaan yang dibentuk oleh waria. Sebagai contoh, di Surabaya terdapat Persekutuan Doa Hati Damai dan Kudus (PHDK) dan Pengajian AlIkhlas, sedangkan di Yogyakarta terdapat Pesantren Waria Senin-Kamis Al-Fatah (Rahmantyo, 2013; Safri, 2014). Keberadaan organisasi keagamaan ini menunjukkan adanya relasi antara waria dan agama. Waria memiliki kerinduan dan keinginan belajar agama, menjalankan ibadah keagamaan dan mendekatkan diri pada Tuhan. Lembaga keagamaan yang ada di masyarakat tidak peka dengan permasalahan ini. Lembaga-lembaga tersebut lebih fokus pada upaya mengembalikan waria pada kodratnya sebagai laki-laki daripada memberikan pelayanan religius yang mereka butuhkan.

Di antara kaum homoseksual di Indonesia, waria merupakan kelompok yang memiliki visibilitas tinggi. Akan tetapi, hal ini tidak lantas menunjukkan adanya penerimaan dari masyarakat terhadap waria (Boellstorff, 2005). Waria masih dipandang rendah dan seringkali mendapat hinaan. Waria dihadapkan pada stigma dan diskriminasi di masyarakat (Arfanda \& Anwar, 2015). Misi lembaga keagamaan untuk mengembalikan waria menjadi lakilaki berdampak pada timbulnya tindakan diskriminatif terhadap waria di tempat peribadatan dan memperkuat stigma yang ada di masyarakat bahwa waria jauh dari nilai-nilai agama.

Keberadaan dua organisasi keagamaan waria di Surabaya menarik perhatian penulis. PHDK adalah organisasi keagamaan yang diperuntukkan bagi waria beragama Kristen Protestan. PHDK didirikan oleh seorang waria bernama Handayani pada tahun 1993 (Rahmantyo, 2013). Kegiatan kerohanian diadakan pada hari jumat minggu kedua setiap bulan di kediaman Handayani. Pengajian Al-Ikhlas adalah organisasi keagamaan yang dikhususkan bagi waria Muslim. Pengajian Al-Ikhlas baru didirikan pada tahun 2003 (Rahmantyo, 2013). Kegiatan rutinnya diadakan setiap Jumat Legi dengan berpindah-pindah tempat. Pengajian ini digabung dengan kegiatan arisan waria, sehingga tempat pengajian ikut menyesuaikan tempat arisan.

Berdasarkan penelitian sebelumnya terkait kedua organisasi keagamaan waria di Surabaya, ditemukan fakta bahwa seorang waria yang sebelumnya dianggap jauh dari nilai-nilai keagamaan memiliki sisi religius (Chasanah, 2017; Rahmantyo, 2013). Akan tetapi, religiusitas waria di Surabaya belum pernah dikaji lebih dalam. Oleh karena itu, penelitian ini akan mengkaji religiusitas waria di Surabaya

Jurnal Lakon: Kajian Sastra dan Budaya 
dengan memanfaatkan teori religiusitas dari Zinnbauer dkk.. Menurut Zinnbauer dan Pergament, religiusitas bersifat formal dan institusional karena merefleksikan komitmen terhadap keyakinan dan praktikpraktik menurut tradisi (keagamaan) tertentu (Amir \& Lesmawati, 2016).

Terdapat empat tanda religiusitas, yaitu penganut suatu agama, altruisme, praktik religius secara pribadi dan manfaat religius bagi diri sendiri (Zinnbauer, Pargament, \& Scott, 1999). Istilah altruisme diciptakan oleh Comte (Campbell, 2006). Comte mengartikan altruisme sebagai "living for others" (hidup untuk orang lain) yaitu tidak semata-mata fokus pada kehidupannya sendiri melainkan peduli dan membantu kehidupan orang lain. Konsep ini diyakininya sebagai salah cara untuk mendekatkan diri pada Tuhan. Zinnbauer dkk. mendefinisikan altruisme sebagai tindakan sukarela dengan memberi dan menolong orang lain (Zinnbauer et al., 1999). Isu lain yang perlu dibahas dalam kajian religiusitas waria adalah hak kebebasan beragama. Penelitian ini perlu melihat implementasi hak kebebasan beragama waria di Surabaya di tengah diskriminasi dan stigma yang mereka alami.

\section{METODE}

Metode yang digunakan pada penelitian ini adalah metode kualitatif. Metode kualitatif diaplikasikan dalam pengumpulan dan analisis data. Data yang dikumpulkan berupa rekaman wawancara terstruktur terhadap dua responden waria pada tanggal 21 September 2018 bertempat di kantor Perwakos (Persatuan Waria Kota Surabaya). Identitas kedua responden dirahasiakan. Pemilihan responden dilakukan secara sengaja (purposive) berdasarkan empat kriteria, yaitu (1) tinggal di Surabaya, (2) menjadi anggota Perwakos, (3) aktif dalam kegiatan keagamaan di Perwakos, dan (4) seorang responden beragama Islam dan seorang lagi beragama Kristen. Pertimbangan di atas sebagai upaya memperoleh representasi autentik dari religiusitas waria yang berada di kota Surabaya serta keterwakilan dari setiap kegiataan keagamaan di Perwakos, yaitu Pengajian Al-Ikhlas dan Persekutuan Doa Hati Damai dan Kudus (PHDK). Data primer berupa hasil transkripsi dari wawancara, sedangkan data sekunder berupa kajian pustaka pada artikel jurnal dan berbagai tulisan terkait keberagamaan waria.

Dua waria yang menjadi responden dalam penelitian ini memiliki latar belakang kehidupan dan agama yang berbeda. Responden A (selanjutnya akan disingkat RA) lahir di Surabaya pada 57 tahun silam. Ia tinggal di wilayah Surabaya Timur bersama seorang laki-laki yang dianggapnya sebagai suami dan seorang anak angkat. Latar belakang pendidikannya cukup tinggi. Ia lulusan SMA dan sempat mengeyam pendidikan di bangku kuliah selama beberapa semester. Saat artikel ini ditulis, ia menjabat sebagai ketua Perwakos. Ia pensiun dari kehidupan malam waria, sebagai pekerja seks, sejak tinggal bersama suaminya yang sekarang.

RA memiliki kos-kosan yang dikhususkan bagi waria. Secara finansial, ia dan keluarga hidup berkecukupan. RA lahir dari kedua orang tua berbeda keyakinan. Ibunya seorang Muslim, sedangkan ayahnya Konghucu. Sewaktu kecil RA beragama Islam kemudian berpindah keyakinan memeluk agama Kristen ketika beranjak remaja. Kedua orang tuanya telah meninggal dunia namun ia tetap hidup dalam keluarga dengan latar belakang 
agama yang berbeda lantaran suami dan anak angkatnya beragama Islam.

Responden B (selanjutnya akan disingkat RB) juga seorang waria kelahiran Surabaya. Saat ini ia berumur 37 tahun. Ia tinggal di wilayah Surabaya Barat bersama keluarga (ibu dan saudara). Ia memiliki suami dengan status istri kedua sehingga tidak memungkinkan tinggal serumah. Pendidikan terakhir RB adalah SMK Seperti halnya RA, RB tidak lagi bekerja sebagai pekerja seks. RB telah memiliki usaha salon kecantikan sendiri. Di Perwakos, ia menjadi Petugas Lapangan (PL) untuk wilayah Surabaya Barat. RB beragama Islam. Ia lahir dan tumbuh dalam keluarga Muhammadiyah. Sejak kecil ia dibentuk menjadi seorang Muslim yang taat. Ia pernah belajar mengaji dan menghapal surah-surah pendek di TPA (Taman Pendidikan Al Qur'an).

\section{PEMBAHASAN}

\section{Representasi Religiusitas Waria di Surabaya}

Zinnbauer dkk. merumuskan empat tanda religiusitas, yaitu penganut suatu agama formal, altruisme, praktik religius secara pribadi dan manfaat religius bagi diri sendiri (Zinnbauer et al., 1999). Berikut penjabaran dari masing-masing tanda religiusitas yang ditemukan pada waria di Surabaya.

\section{Agama}

RA dan RB adalah waria yang menganut suatu agama serta aktif dalam organisasi keagamaan. RA beragama Kristen (Protestan) sedangkan RB beragama Islam (Muhammadiyah). RA lahir dari orang tua yang berbeda keyakinan. Ibunya seorang Muslim keturunan Madura, sedangkan ayahnya pemeluk agama Konghucu beretnis Tionghoa. Sewaktu kecil RA merupakan seorang Muslim seperti ibunya. Ketika berumur enam belas tahun RA memutuskan berpindah agama Kristen.

RA menjelaskan alasannya berpindah keyakinan sebagai berikut:

"Karena waktu itu kan sulit sekali rasanya pagi harus bangun, sholat harus bangun. Jadi, terus saya kok pilih enaknya terus masuk Kristen dan lagian itu papa saya orangnya Konghucu gitu loh. Saya kalau ikut papa saya Konghucu, gak enak mama saya. Mama saya Islam. Terus kalau ikut mama saya Islam, terus gak enak papa saya. Jadi, saya ambil jalur tengahnya. Saya ambil Kristen." (Wawancara dengan Responden A, 21 September 2018).

Dari kutipan diatas, terdapat dua faktor yang mendorong RA berpindah keyakinan, yaitu (1) RA mengalami kesulitan menjalankan ibadah seperti salat Subuh yang mengharuskannya bangun di pagi hari dan (2) RA merasa tidak enak hati apabila memeluk satu agama dari salah satu orang tuanya. Adapun keputusannya menjadi seorang Kristiani berkat pengaruh seorang teman sesama waria yang aktif di kegiatan keagamaan Kristen:

"Itu ikut Handayani. Handayani kan teman saya. Terus, 'kamu ikut Persekutuan saja.' 'Lho saya orang Islam kok ikut persekutuan?' Terus Handayani bilang, 'Gak apa-apa ikut saja'. Saya ikut Persekutuan, terus tak pikir-pikir, 'Loh kok enak? Gak soro. Cuma berdoa gitu tok' (tertawa). Terus akhirnya saya mantep di Kristen itu." (Wawancara dengan Responden A, 21 September 2018). 
Berbeda dengan RA, RB sejak kecil menganut agama Islam. Ia lahir di keluarga Muhammadiyah yang taat. RB kecil memperoleh pendidikan agama yang memadai seperti penuturannya di bawah ini:

"(Menjadi seorang Muhammadiyah) Sebenarnya bukan pilihan. Memang sudah terbentuk dari keluarga... Seperti yang saya bilang, kedua orang tua saya itu agamis banget. Jadi dari kecil itu aku sempat, bukan sempat ya tapi memang ngaji! Ikut pendidikan ngaji, TPA. Bahkan TPA di tempatku itu adalah inisiasi sebelum ada TPA-TPA lain. Bahkan ngajinya juga ada wisudanya sekalian. Sampai hafal surat-surat." (Wawancara dengan Responden B, 21 September 2018).

Afiliasi pada suatu agama formal merupakan tanda utama dari religiusitas waria (Zinnbauer et al., 1999). Waria yang tidak menganut agama tertentu tetapi memiliki kepercayaan terhadap realitas yang hakiki tidak memenuhi syarat dalam konsep religiusitas melainkan spiritualitas, yaitu melakukan ekspresi spritualitas nonreligius (Amir \& Lesmawati, 2016). Selain menganut suatu agama, mereka juga aktif dalam kegiatan organisasi keagamaan. Organisasi keagamaan yang mereka ikuti berada di bawah naungan Perwakos, yaitu Persekutuan Doa Hati Damai dan Kudus (PHDK) untuk waria beragama Kristren Protestan dan Pengajian Al-Ikhlas untuk waria Muslim. RA menjabat sebagai wakil ketua di PHDK, sedangkan RB menjadi anggota non-aktif di Pengajian Al-Ikhlas. Keikutsertaan mereka dalam organisasi tersebut memiliki tujuan untuk menjalankan ibadah serta mempelajari agama masing-masing.
Sejak terjun menjadi waria, ikatan mereka sebagai penganut suatu agama dengan tempat peribadatan mengalami perubahan. RA lambat laun jarang pergi ke gereja dikarenakan adanya diskrimasi dari pendeta dan jemaat gereja. RA bercerita:

"Kalau sama pendetanya itu, kadangkadang saya itu masalah khotbahnya itu. Ada waria disitu, khotbahnya kadang-kadang. 'Oh lagi ada waria'. Itu supaya waria itu sadar, supaya jadi laki, tapi bukan membuat saya sadar sebetulnya, bikin saya sakit hati itu malah. Kadang-kadang kan khotbahnya gini, 'Orang di dunia itu hanya ada hitam dan putih saja. Gak ada abu-abu, gak ada,' katanya gitu. Jadi maksudnya itu orang di dunia ini hanya ada lakilaki dan perempuan, waria itu ndak ada. Bahwa waria itu sudah menyimpang dari Tuhan. Bahwa itu akan, apa itu namanya, dosa. Perbuatan yang berdosa. Terus saya kan, 'Kenapa kok begini?' Saya itu mau pulang, berdiri itu kaki rasanya. Orang kan akhirnya tambah tertuju pada saya, karena yang diomongkan adalah waria dan ada waria disitu. Akhirnya pulang itu mereka itu langsung tertujunya ke saya. Lihaaat aja. Lihaaat aja. Saya lamakelamaan agak, agak. Biasanya setiap minggu, akhirnya satu bulan, akhirnya tidak sama sekali. Cuma kalau di Handayani (kebaktikan di PHDK), saya selalu aktif disitu." (Wawancara dengan Responden A, 21 September 2018).

RA lebih lanjut menuturkan bahwa di PHDK, ia dan waria lainnya tidak mendapatkan perlakuan diskriminatif lantaran adanya koordinasi dengan pihak pendeta terlebih dahulu sehingga dapat mencegah pendeta menyampaikan 
perkataan yang dapat menyinggung para waria:

"Di Handayani (PHDK) itu kalau ada pendetanya, sudah diomongi Handayani itu. Jadi jangan sampai, "khotbah jangan sampai menyinggung jemaat saya. Jemaat sini ada enam puluh ini waria semua. Jadi jangan sampai menyinggung ya." (Wawancara dengan Responden A, 21 September 2018).

Sebagai seorang waria Muslim, RB tidak pernah mengalami diskriminasi di masjid. Hal ini dikarenakan RB tidak pernah pergi ke masjid semenjak menjadi waria. RB bercerita:

"Kalau ke masjid ini udah lama gak. Ketika aku sudah memberanikan diri berpenampilan perempuan, aku sudah gak pernah ke masjid. Ke langgar, iya. Tapi bukan untuk ibadah, zakat itu mesti tiap tahun. Atau mungkin ngasih, ngasih ya, kadang orang tadarus tu loh mbak. Kesana itu bukan untuk ibadah. Kalau ibadah mesti di rumah. (Sholat Ied) itu aku gak pernah ikut (tertawa). Sholat jumat malah gak. (Wawancara dengan Responden B, 21 September 2018).

Kutipan di atas menunjukkan bahwa RB memilih menghindari beribadah di masjid yang notabenenya merupakan tempat ibadah bagi masyarakat Muslim umum. RB menjelaskan alasannya sebagai berikut:

"Kalau trauma tidak ada. Aku menstigma diri aku sendiri. Sebenarnya aku selesai ya dengan diriku untuk di sosial, tapi untuk di agama itu aku belum selesai karena belum berani memposisikan diriku ke masjid, di barisan mana seperti itu. Sekarang aku sholat di rumah pakai mukena loh! (Ke masjid pakai mukena) belum berani aku! Belum berani. Karena waria ini mereka (masyarakat) melihatnya masih memiliki alat kelamin laki-laki (sehingga harus sholat di barisan lakilaki). Gitu sih." (Wawancara dengan Responden B, 21 September 2018).

Penjelasan RB di atas mengungkapkan bahwa alasan utama ia menghindari beribadah ke masjid adalah kebingungannya untuk bergabung dengan barisan perempuan atau barisan laki-laki ketika berada masjid. Sebagai waria, RB masih dianggap oleh masyarakat sebagai laki-laki sehingga ia harus bergabung dengan barisan laki-laki padahal RB sendiri merasa sebagai seorang perempuan serta berpenampilan perempuan (memakai mukena) yang menurutnya ia seharusnya bergabung dengan barisan perempuan. Ketidakjelasan posisinya di masjid inilah yang menghambatnya datang beribadah ke masjid sehingga memilih menjalankan ibadah di rumah.

\section{Altruisme}

RA dan RB memiliki kepedulian terhadap sesama, baik terhadap sesama waria ataupun masyarakat. Salah satu hal yang menjadi perhatian keduanya adalah bahaya HIV/AIDS bagi waria. Waria merupakan salah satu kelompok minoritas yang berisiko tinggi tertular HIV/AIDS (Yulianingtias \& Harmanto, 2016). Di bawah naungan Perwakos, mereka berdua memberi penyuluhan bagi waria tentang bahaya HIV/AIDS, mendampingi tes VCT (Voluntary Counseling Test), dan memberi dorongan semangat pada ODHA (Orang Dengan HIV/AIDS). Apabila ada waria yang terkena razia Satpol PP Surabaya, RA

Jurnal Lakon: Kajian Sastra dan Budaya 
sebagai ketua Perwakos bertanggung-jawab membebaskan mereka. Tidak jarang dia menggunakan uang pribadi demi mengeluarkan mereka dari Liponsos (Lingkungan Pondok Sosial).

Selain berbagi dan menolong sesama waria, RB juga berbagi kebaikan terhadap masyarakat umum. RB memiliki prinsip bahwa beramal zakat tidak akan membuat hartanya berkurang justru akan menambah keberkahan. Inilah yang kemudian mendorongnya berbagi dengan masyarakat sekitar. RB rutin membayar zakat fitrah di langgar setiap tahun dan menyumbang makanan untuk tadarusan serta kegiatan warga lainnya. RB juga mengajak waria lainnya untuk mengikuti langkahnya:

"Aku mengumpulkan teman-teman. 'Kegiatan positif apapun yang diadakan di RT RW, ikuti! Kerja bakti, ikut! Aku gak bisa ngasih tenaga, kasih materi! Bakti sosial di kecamatan, bakti sosial karang taruna bagi-bagi sembako untuk janda-janda, kita ikut. Kita urunan." (Wawancara dengan Responden B, 21 September 2018).

Uraian di atas menunjukkan adanya perilaku altruisme dari keduanya serta waria-waria lain yang diartikan sebagai tindakan sukarela dengan memberi dan menolong orang lain (Zinnbauer et al., 1999).

3. Praktik religius secara pribadi

RA mengaku memiliki kedekatan dengan Tuhan. Baginya Tuhan adalah tempat berkeluh kesah. Masyarakat di sekitarnya seringkali menyalahkannya atas kemalangan yang menimpa dirinya. RA bercerita bahwa orang yang diajaknya berbicara mengenai masalah pribadinya selalu berbalik mengatakan, "salahmu dewe wong, wong opo, anae lanang, lanang dadi wedok! (salahmu sendiri, terlahir laki-laki malah jadi perempuan!)" (Wawancara dengan Responden A, 21 September 2018). RA menganggap Tuhan layaknya orang tua yang keberadaannya dekat dan senantiasa membimbing anak-anaknya. Dalam urusan beribadah, RA jarang pergi ke gereja di hari minggu namun ia selalu hadir dalam kegiatan kerohanian di PDHK pada jumat kedua setiap bulan. Ia menyanyikan lagu gereja di sela-sela kesibukannya mengurus anak di rumah dan memanjatkan doa ketika mengalami kesulitan dan kebahagiaan.

RB merasa belum ada kedekatan secara personal dengan Tuhan. Ia belum bisa melaksakan semua kewajibannya sebagai seorang Muslim terutama dalam menjalankan ibadah salat lima waktu. Di saat ia menyadari umurnya semakin bertambah tua, ia mengaku mulai mengingat Tuhan. Ia berusaha menjalankan salat setiap hari meskipun tidak lengkap lima waktu di rumah. Berikut penuturan RB:

"Semakin kesini aku sudah mulai ingat sama Yang Kuasa. Maksudnya melakukan ibadah sholat meskipun tidak lima waktu, tapi saya berusaha untuk sholat. Meskipun cuma Maghrib ataupun Subuh." (Wawancara dengan Responden B, 21 September 2018)

\section{Manfaat religius}

Agama berperan penting dalam kehidupan seseorang. Zinnbauer dkk. menyebutkan bahwa agama memiliki fungsi membantu seseorang menghadapi persoalan mengenai eksistensi diri, seperti makna kehidupan, kematian, penderitaan dan ketidakadilan (Zinnbauer et al., 1999). RA memaknai agama sebagai penuntun jalan hidup. Agama menuntunnya pada 
jalan yang benar. Agama memberikannya dorongan semangat menghadapi permasalahan hidup. Agama juga menjanjikan pengampunan ketika dia meninggal. RA merasa hidupnya lebih tentram dengan beragama.

RB menyadari pentingnya agama dalam kehidupan di dunia. Ia meyakini bahwa Tuhan selalu hadir memberinya pertolongan. Setelah melakukan ibadah salat dan berdoa, ia menemukan jalan keluar bagi masalah yang dihadapinya. RB bercerita:

"Satu hal itu saya sangat yakin dan memang benar-benar bisa menolong ketika saya ada masalah dan mencoba mencari solusi kasarannya begitu. Kalau tidak ada titik temu sempat sholat dan memang ada jawaban disana gitu loh. Contoh kecil misalnya rejeki atau apa ya, kepepet apa gitu ya, menurut aku itu kesulitan dalam hidup dan itu mesti ada jalan. Meskipun jalan keluarnya istilah kasarannya pinjeman hutang tapi menurutku itu sudah jawaban. Pertolongan. Itu contoh kecil." (Wawancara dengan Responden B, 21 September 2018)

\section{Hak Kebebasan Beragama bagi Waria di Surabaya}

RA dan RB sepakat bahwa waria di Surabaya mendapatkan kebebasan memeluk agama yang diyakininya tanpa adanya paksaan atau larangan dari orang lain. Namun, dalam menjalankan ibadah menurut agama masing-masing di rumah ibadah mereka mengalami banyak hambatan. Hambatan tersebut umumnya datang dari jemaah dan pemuka agama yang bertindak diskriminatif terhadap waria. RA menceritakan pengalaman diskriminatif di gereja sebagai berikut:

"Jemaahnya gitu. Kadang-kadang tahu saya ada, waria gitu. Terus ada laki-laki duduk gini itu sama istrinya ya terus dia itu kaya apa itu menyingkir gitu, terus perempuannya suruh deket sama saya. Tapi misalnya disitu ada bangku kosong, mereka itu pindah. Kalau sudah penuh, terus terpaksa berdekatan sama saya. Tapi yang perempuan. (Duduknya) Agak menjauh. Tapi kalau sudah penuh, terpaksa dempetan." (Wawancara dengan Responden A, 21 September 2018)

Kutipan ini menunjukkan sikap jemaat gereja yang enggan duduk bersama waria. Sikap ini termasuk tindakan diskriminatif karena mereka telah memperlakukan waria secara berbeda dibandingkan jemaat lainnya.

Berbeda dengan RA, RB belum pernah mengalami diskriminasi di masjid lantaran ia tidak pernah beribadah di masjid setelah menjadi waria. Ia menginternalisasi gagasan bahwa waria menyalahi ajaran agama sehingga ia menstigma dirinya sendiri. Ini tidak hanya terjadi pada $\mathrm{RB}$, namun juga terjadi pada banyak waria Muslim lainnya. Mengenai kebebasan menjalani ibadah keagamaan, RB menuturkan:

"Ya itu. Bebas ini berarti bisa penerimaan ya mbak? (Bebas) beribadah di manapun dan berhak gitu. Begini loh tidak ada satupun tempat ibadah yang mengharamkan atau tidak membolehkan teman-teman (waria) untuk beribadah disana. Cuma temanteman itu menstigma dirinya sendiri aja. Cuma kalau bebas, gak bebas sih. Tapi

Jurnal Lakon: Kajian Sastra dan Budaya e-ISSN: 2527-4899; p-ISSN 2252-8954 
kalau aku rame-rame gitu berani. Kalau sendiri, maksudnya dulu (jemaah) AlIkhlas ada (wisata) religi ke sunansunan itu masuk masjid, (aku) ikut. Masuk masjid berani kalau rame-rame. Kalau sendiri gak berani." (Wawancara dengan Responden B, 21 September 2018)

Penuturan RB menegaskan bahwa tidak ada larangan bagi waria untuk beribadah di rumah ibadah. Perasaan khawatir atau ketakutan atas penolakan dari jemaah yang menjadi pemicu bagi waria menghindari beribadah di rumah ibadah. Hal ini menunjukkan bahwa rumah ibadah belum bisa memberikan rasa aman bagi para waria sehingga mereka enggan melaksakan ibadah di tempat tersebut.

\section{SIMPULAN}

Religiusitas waria di Surabaya dapat dipahami dengan melihat latar belakang kehidupan dan agama, representasi religiusitas, dan persoalan keagamaan yang mereka hadapi seperti diskrimasi, stigma dan hak kebebasan beragama. Waria di Surabaya memiliki latar belakang kehidupan dan agama yang beragam. Terdapat sisi religius dalam diri mereka yang tidak diketahui masyarakat luas. Waria menganut suatu agama formal seperti agama Islam dan Kristen. Mereka menjalankan ibadah keagamaan meskipun tidak sempurna. Mereka berperilaku altruistik seperti yang diajarkan agama. Mereka juga memperoleh manfaat dari keimanan mereka terhadap agama masingmasing. Dalam menjalankan ibadah menurut agamanya, waria dihadapkan pada persoalan klasik yaitu diskriminasi dan stigma. Fenomena ini menunjukkan bahwa waria di Surabaya belum sepenuhnya mendapatkan kebebasan beragama. Mereka bebas memeluk agama tertentu, tetapi mereka masih mengalami hambatan dalam menjalankan praktik keagamaannya.

\section{DAFTAR PUSTAKA}

Amir, Y., \& Lesmawati, D. R. (2016). Religiusitas dan spiritualitas: konsep yang sama atau berbeda? Jurnal Ilmiah Penelitian Psikologi: Kajian Empiris \& Non-Empiris, 2(2), 67-73.

Arfanda, F., \& Anwar, S. (2015). Konstruksi Sosial Masyarakat Terhadap Waria. KRITIS : Jurnal Ilmu Sosial Dan Ilmu Politik Universitas Hasanuddin, 1(1), 93-102.

Boellstorff, T. (2005). The Gay Archipelago: seksualitas dan bangsa di Indonesia. New Jersey: Princeton University Press.

Campbell, R. L. (2006). Altruism in Auguste Comte and Ayn Rand Did Rand Misunderstand Altruism? The Journal of Ayn Rand Studies, 7(2), 357-369.

Chasanah, N. C. (2017). Aktivitas sosial keagamaan komunitas Waria di Surabaya (undergraduate). UIN Sunan Ampel Surabaya.

Faidah, M., \& Abdullah, H. (2013). Religiusitas dan Konsep Diri Kaum Waria. JSGI, 4(1), 1-14.

Latiefah, U. (2013). Pesantren Waria dan Kosntruksi Identitas. Jurnal Pemikiran Sosiologi, 2(1), 87-96.

Praptoraharjo, I., Navendorff, L., \& Irwanto. (2015). Survei Kualitas Hidup Waria. Pusat Penelitian HIV dan AIDS, Unika Atma Jaya. Jakarta.

Rahmantyo, L. E. (2013). Waria dan Upayanya dalam meraih kapital simbolik : Studi Kasus Pengajian AlIhklas dan Persekutuan Doa Hati Damai dan Kudus. Lakon: Jurnal 
Kajian Sastra Dan Budaya, 1(2), 6281.

Safri, A. N. (2014). Pesantren Waria SeninKamis Al-Fatah Yogyakarta: Sebuah Media Eksistensi Ekspresi Keberagamaan Waria. ESENSIA, 15(2), 251-260.

Yulianingtias, E., \& Harmanto. (2016). Partisipasi Persatuan Waria Kota Surabaya (Perwakos) dalam Kebijakan Penanggulangan HIV/Aids di Surabaya. Kajian Moral Dan Kewarganegaraan, 2(4), 425-440.

Zinnbauer, B. J., Pargament, K. I., \& Scott, A. B. (1999). The Emerging Meanings of Religiousness and Spirituality: Problems and Prospects. Journal of Personality, 67(6), 889-919.

\section{WAWANCARA}

Responden A, 57 tahun, waria beragama Kristen Protestan, wawancara pada 21 September 2018.

Responden B, 37 tahun, waria beragama Islam Muhammadiyah, wawancara pada 21 September 2018. 